\title{
Pengembangan Model Pembelajaran Berbasis Permainan Sirkuit Untuk Meningkatkan Motorik Halus Anak Usia 4-5 Tahun
}

\author{
Made Vina Arie Paramita ${ }^{(1)}$ Panggung Sutapa ${ }^{(2)}$ \\ Universitas Pendidikan Ganesha $^{(1)}$, Universitas Negeri Yogyakarta ${ }^{(2)}$ \\ vina.arie.paramita@gmail.com/panggung_s@uny.ac.id
}

\begin{abstract}
Abstrak
Penelitian ini bertujuan untuk: (1) mengembangkan model pembelajaran berbasis permainan sirkuit yang sesuai dengan perkembangan anak usia dini, (2) mengetahui keefektifan penerapan model pembelajaran berbasis permainan sirkuit terhadap motorik halus anak pada usia 4-5 tahun. Jenis penelitian ini adalah penelitian dan pengembangan (Research and Development $(R \& D))$. Subyek penelitian pada penelitian ini adalah anak usia 4-5 tahun. Teknik dan instrument pengumpulan datanya adalah dengan menggunakan wawancara, lembar observasi dan lembar validasi atau angket. Teknik analisis data uji efektivitas yang digunakan adalah dengan analisis statistik nonparametrik Uji Wilcoxon atau uji tanda. Hasil Pengembangan Model Pembelajaran Berbasis Permainan Sirkuit berisi langkah-langkah yang didalamnya terdiri dari beberapa pos kegiatan permainan, dan didokumentasikan dalam bentuk $\mathrm{CD}$ dan buku panduan pelaksanaan pembelajaran. Langkah-langkah pembelajaran yang terdiri dari kegiatan awal, kegiatan pemanasan, kegiatan inti (permainan sirkuit), dan kegiatan akhir (pendinginan). Hasil dari validasi yang dilakukan ahli dan juga guru didapatkan bahwa produk yang dikembangkan masuk kedalam kategori "baik". Pengembangan model pembelajaran berbasis permainan sirkuit dinyatakan efektif dalam meningkatkan motorik halus anak.
\end{abstract}

Kata Kunci: Usia 4-5 Tahun; Model Pembelajaran Berbasis Permainan Sirkuit; Motorik Halus.

\begin{abstract}
This study aimed to: (1) develop a circuit-based learning model appropriate to early childhood development, and (2) to know the effectiveness of the application of circuit-based learning model to the children's fine motor at the age of 4-5 years. This type of research is Research and Development. This type of research is research and development (R \& D). Research subjects in this study were children aged 4-5 years. The technique and instrument of data collection is by using interview, observation sheet and validation sheet or questionnaire. The data analysis technique of effectiveness test used is by nonparametric statistic analysis Wilcoxon test or sign test. The Result of Developing a Game Based Learning Model The Circuit contains steps in which it consists of several game activity postings, and is documented in the form of CDs and instructional instruction manuals. Learning steps consisting of preliminary activities, warm-up activities, core activities (circuit play), and end activities (cooling). The results of validation by experts and also teachers found that the products developed into the category of "good". The development of circuit-based learning model is declared effective in improving children's fine motor.
\end{abstract}

Keyword: Age 4-5 Years; Circuit-Based Learning Model; Fine Motor skill, . 


\section{PENDAHULUAN}

Anak merupakan generasi penerus bangsa yang memerlukan perhatian khusus dalam tumbuh kembang. Setiap anak memiliki pertumbuhan dan perkembangan yang berbeda-beda sesuai dengan kebutuhan, sehingga anak disebut pribadi yang unik. Hal ini sejalan dengan pendapat Piaget (Mutiah, 2012:53) menyatakan "anak lahir dengan segala keunikan potensi, yang antara satu dengan yang lainnya tidak sama, bahkan anak kembar sekali pun". Hal ini mengartikan bahwa setiap anak adalah unik karena memiliki watak, perawakan yang berbeda-beda.

Keunikan pada anak juga terlihat pada proses perkembangan. Anak usia dini merupakan kelompok anak yang berada dalam proses pertumbuhan dan perkembangan yang bersifat unik, artinya memiliki pola pertumbuhan dan perkembangan fisik (koordinasi motorik kasar dan motorik halus), kecerdasan (daya pikir dan daya cipta), sosio emosional, bahasa dan komunikasi. Seluruh aspek perkembangan baik fisik motorik, kognitif, bahasa, dan sosial emosional anak akan berkembang sesuai dengan tahapan perkembangan. Setiap aspek perkembangan anak tersebut secara umum memiliki pola atau tahapan perkembangan yang sama, namun pencapaian setiap anak terhadap masing-masing aspek perkembangan yang berbeda. Perbedaan ini karena dipengaruhi dari kesiapan atau biasanya disebut masa peka.

Masa peka merupakan kondisi kesiapan anak dalam menerima rangsangan atau stimulus. Artinya, pada masa ini mempermudah anak dalam mempelajari dan membangun pola pikir tentang segala sesuatu yang berada di sekitar tanpa merasa ada kesulitan. Hal ini sependapat dengan Montessori (Yus, 2011:p.8) yang meyakini bahwa "dalam tahun-tahun awal kehidupan, seorang anak mempunyai masa peka". Masa peka dapat digambarkan sebagai suatu situasi atau waktu siap berkembang pembawaan atau potensi yang dimiliki anak. Potensi ini akan lenyap dan tidak akan muncul lagi apabila anak tidak diberikan kesempatan untuk berkembang tepat pada waktunya. Oleh karena itu, masa peka merupakan masa yang sangat penting dalam perkembangan seorang anak. Saat anak berada pada masa peka, maka anak harus distimulasi dengan cara yang sesuai prinsip pembelajaran anak yakni bermain

Bermain merupakan kegiatan yang sangat penting bagi pertumbuhan dan perkembangan anak. Kata "bermain" tidak lepas dari anak usia dini. Seluruh kegiatan anak 
lakukan dengan bermain. Bermain dilakukan dengan rasa senang dan aktif, sehingga kegiatan bermain tersebut menghasilkan proses belajar pada anak. Suasana yang senang, aktif, nyaman dan santai membuat anak tidak merasa tertekan, sehingga anak dapat menikmati kegiatan bermain. Bermain dapat digunakan sebagai media untuk menguatkan ketrampilan dan kemampuan tertentu pada anak.

Kegiatan bermain merupakan cara terbaik menstimulasi anak untuk belajar mengekspresikan perasaan, pikiran dan pandangan terhadap seni (Hayati, 2012:p.3). Banyak manfaat yang didapatkan oleh anak melalui bermain, seperti anak membangun pengetahuan, menjalin interaksi sosial dengan anak lain, melatih panca indra, melatih fisik-motorik, meningkatkan kemampuan bahasa yang dimiliki, melatih kesabaran, meningkatkan jiwa empati dan saling berbagi. Pada perkembangan aspek fisik, anak berkesempatan melakukan kegiatan yang melibatkan gerakan tubuh dan melatih otot-otot tubuh. Bermain membutuhkan gerakan dan koordinasi tubuh, sehingga dengan bermain anak dapat melepaskan ketegangan yang ada dalam dirinya. Anak akan menyalurkan perasaan dan dorongan-dorongan yang membuat anak merasa lebih lega dan relaks. Pada dasarnya, melalui bermain akan menstimulasi seluruh aspek perkembangan anak.

Aspek perkembangan anak saling berkaitan yang satu dengan yang lainnya. Seluruh aspek perkembangan harus distimulasi dengan berbagai kegiatan yang menyenangkan. Salah satu aspek perkembangan yang wajib distimulasi adalah perkembangan fisik-motorik. Perkembangan fisik menjadi dasar, artinya disini adalah pertama kali yang dapat anak lakukan dalam menanggapi respon melalui gerakan. Anak menggenggam, menoleh, menendang-nendang, dan lain sebagainya merupakan bagian dari perkembangan fisik.

Perkembangan fisik ada dua aspek, yakni perkembangan motorik kasar dan perkembangan motorik halus. Istilah fisik motorik menggambarkan semua gerakan tubuh dan diklasifikasikan menjadi motor kasar dan perilaku motorik halus. Saat melakukan keterampilan motorik kasar seperti berdiri, berjalan, melompat, berlari, dengan menggunakan otot kaki dan lengan besar atau seluruh tubuh, sedangkan pada saat melakukan ketrampilan motorik halus seperti melibatkan koordinasi gerakan mata dan jari (Balasubramanian, 2013:p.1). Perkembangan motorik kasar lebih mengarah pada kegiatan yang melibatkan otototot besar, sebagai contoh anak melompat, merangkak, berlari, berjalan, dan lain sebagainya. Motorik kasar anak akan berkembang dengan sendirinya, sehingga disaat anak sudah siap maka dengan sendirinya akan melakukan kegiatan tersebut tanpa bantuan orang dewasa. Disisi lain, perkembangan motorik halus anak mengarah pada kemampuan mengendalikan, 
ketangkasan dan koordinasi mata dengan jari. Contoh dari kegiatan motorik halus adalah menggenggam, menggunting, menjimpit, merobek, dan lain sebagainya. Berbeda dengan motorik kasar anak, motorik halus anak tidak dapat berkembang optimal dengan sendirinya, sehingga diperlukan rangsangan atau stimulus yang mampu mengoptimalkan motorik halus anak.

Motorik halus digunakan dalam kegiatan pada kehidupan sehari-hari dan pada akademik. Kegiatan pada perkembangan motorik halus yang biasa dilakukan dalam kehidupan sehari-hari, contohnya menyikat gigi, memakai pakaian, menggunakan sendok dan garpu, mengikat tali sepatu, dan lain sebagainya. Pada kegiatan akademik yang biasa dilakukan anak seperti menulis, menggunting, mewarnai, melipat, menggambar dan menarik garis, dan lain sebagainya. Seiring dengan banyaknya penguasaan keterampilan motorik halus yang dimiliki anak semakin baik prestasi di sekolah, dengan demikian, perkembangan motorik halus anak perlu diperhatikan. Berk (Ali 2017:p.12) berpendapat bahwa "perkembangan motorik halus adalah pengembangan dan pengendalian keterampilan gerakan kecil, seperti mencapai dan menggenggam, sementara pengembangan motorik kasar mengacu pada kontrol terhadap keterampilan gerakan yang lebih besar yang cenderung kurang disempurnakan, seperti merangkak, berdiri dan berjalan".

Potensi-potensi yang harus dikembangkan pada motorik halus adalah kegiatankegiatan yang menggunakan otot-otot kecil pada tangan. Kegiatan ini termasuk memegang benda kecil seperti manik-manik, butiran kalung, memegang pensil dengan benar, menggunting, mengikat tali sepatu, mengancing dan menarik resleting. (Kurniasih 2009:p.29-30).

Kemampuan motorik halus (Abd, 2016:p.1) adalah pola gerakan untuk memanipulasi objek dengan menggunakan otot kecil tangan dan jari. Fakhruddin (2010:p.118) menyatakan bahwa "motorik halus adalah meningkatkan pengoordinasikan gerak tubuh yang melibatkan kelompok otot dan saraf yang lebih kecil”. Kelompok otot dan saraf inilah yang nantinya mampu mengembangkan gerak motorik halus, misal, merobek, menggambar dan menulis. Sejalan dengan pendapat tersebut, Suyadi (2010:p.69) menyatakan bahwa "perkembangan motorik halus adalah meningkatnya pengoordinasian gerak tubuh yang melibatkan otot dan syaraf yang jauh lebih kecil atau detail". Hal ini sejalan dengan Johnson \& Haloca (2010:p.54) bahwa "Fine motor skills are those manipulative skills that involve small movements and small muscles in parts of the body, such as picking up, feeding 
themselves, threading, drawing, cutting and dressing. Fine motor skills develop slightly later than gross motor skills and need patience and practice to develop". Keterampilan motorik halus adalah kemampuan manipulatif yang melibatkan gerakan dan otot-otot kecil pada bagian tubuh. Pengembangkan kemampuan motorik halus harus membutuhkan kesabaran dan latihan untuk berkembang.

Pada dasarnya perkembangan ini berkembang sejalan dengan kematangan saraf dan otot anak. Sehingga, setiap gerakan sesederhana apapun, adalah merupakan hasil pola interaksi yang kompleks dari berbagai bagian dan sistem dalam tubuh yang dikontrol oleh otak. Perkembangan motorik sebagai perkembangan dari unsur kematangan dan pengendalian gerak tubuh.

Fakta yang ada di lapangan, masih ada yang selalu mengedepankan akademik anak tanpa memperhatikan kesiapan anak. Contohnya, anak sudah diajarkan menulis tanpa melihat apakah anak sudah siap memegang pensil, apakah otot-otot anak sudah mampu. Anak lebih senang melakukan kegiatan di luar ruangan karena anak merasa lebih renggang dan bebas, namun sebagian besar kegiatan pembelajaran masih dilakukan di dalam ruangan kelas. Kegiatan yang dilakukan di dalam ruangan kelas dengan menggunakan lembar kerja anak (LKA). Kegiatan- kegiatan pembelajaran lebih sering bersifat individual dan masih bersifat monoton. Pembelajaran masih bersifat konvensional, guru masih menjadi pusat segalanya. Hal tersebut mengakibatkan anak merasa bosan dan kurang begitu tertarik dengan pembelajaran, sehingga membutuhkan inovasi model pembelajaran yang menarik perhatian anak.

Berdasarkan fakta tersebut ada 3 masalah yang muncul, yakni: (1) pembelajaran masih mengedepankan akademik seperti membaca, menulis dan berhitung, sehingga kurangnya perhatian untuk merangsang perkembangan motorik halus anak; (2) kegiatan pembelajaran sebagian besar masih dilakukan di dalam kelas, sehingga anak kurang memiliki variasi kegiatan di luar ruangan yang menyebabkan anak mudah bosan melakukan kegiatan di dalam kelas; (3) alternatif kegiatan pembelajaran dalam menstimulus motorik halus anak kurang bervariasi, sehingga anak cenderung tidak mau menyelesaikan pekerjaan.

Berdasarkan masalah tersebut penelitian ini mengembangkan suatu konsep atau model pembelajaran untuk anak usia dini. Model pembelajaran akan menunjang proses pembelajaran. Joyce \& Weil (Rusman, 2011:p.133) menyatakan bahwa "model pembelajaran adalah suatu rencana atau pola yang dapat digunakan untuk membentuk kurikulum (rencana 
pembelajaran jangka panjang), merancang bahan-bahan pembelajaran, dan membimbing pembelajaran di kelas atau pada tempat lain".

Joyce (1992:p.4) mengemukakan ada lima unsur pembelajaran yakni, sintaks, prinsip reaksi, sistem sosial, sistem pendukung, serta dampak instruksional dan dampak pengiring.

Kegiatan atau aktivitas pembelajaran disesuaikan dengan kondisi kelas dan lingkungan sekitar. Lingkungan yang kondusif, aman dan nyaman akan berpengaruh positif pada proses pembelajaran. Selain lingkungan, model pembelajaran diterapkan guru juga berpengaruh dalam proses pembelajaran. Joyce \& Weil (Winataputra, 2001:p.4) mengelompokkan model pembelajaran ke dalam empat katagori, yakni Model Pengelolaan Informasi, Model Personal, Model Sosial, dan Model Sistem Perilaku.

Pembelajaran yang baik adalah pembelajaran yang kegiatannya disenangi anak, sehingga anak menerima pembelajaran dengan perasaan tanpa beban. Bergen (2009:p.414) mengatakan "kunci dari bermain adalah menyenangkan. Jika suatu aktivitas tidak memberikan kesenangan, maka tidak bisa dikatakan bermain. Bermain mencakup pengendalian internal,motivasi internal, dan realitas internal". Hurlock (1978:p.320) "bermain adalah proses kegiatan aktivitas yang menyenangkan yang akan menimbulkan kesenangan tanpa memikirkan dampak yang akan ditimbulkan”. Kegiatan bermain tidak berdasarkan unsur paksaan atau berdasarkan adanya tekanan baik dari luar maupun dari dalam individu. Proses kegiatan bermain tidak memiliki aturan yang baku, akan tetapi biasanya aturan yang ada dibuat oleh setiap individu yang melakukan kegiatan bermain itu sendiri.

Isenberg \& Jalongo (Madyawati, 2016:p.146) menyebutkan “dengan bermain sangat mendukung pertumbuhan dan perkembangan anak. Anak mulai untuk mengerti dunia, mampu mengembangkan pemikiran yang fleksibel dan berbeda serta memiliki kesempatan menemukan dan mengatasi permasalahan-permasalahan yang sebenarnya". Bermain merangsang pemikiran anak dalam memproses pemecahan masalah yang ditemuinya. Dengan demikian anak akan semakin mengerti solusi yang harus diberikan pada setiap masalah yang ditemui. Hal ini sejalan dengan pendapat Vos (Hong, Mei, dkk, 2016:p.241) yang menyatakan "bermain dapat memfasilitasi kegiatan "trialand error" bagi anak yang bertujuan untuk meningkatkan pengetahuan dan keterampilan yang diperoleh dari aktivitas bermain”. Whitebread (2012:p.4) berpendapat bahwa anak-anak terlibat dalam lima jenis permainan utama, yakni bermain fisik, bermain dengan benda, permainan simbolis, permainan purapura/sosiodramatis, dan permainan dengan peraturan. 
Permainan yang digunakan dalam mengembangkan kemampuan motorik halus anak berupa permainan sirkuit. Permainan Sirkuit merupakan modifikasi dari sirkuit training, pengertian dari permainan sirkuit tidak jauh beda dari latihan sirkuit yakni kegiatan yang terdiri dari serangkaian bentuk latihan yang dilakukan. Wastcott (2003:p.173), menyebutkan sirkuit merupakan model latihan yang dilakukan secara berurutan dan terus menerus selama satu putaran/sirkuit yang melibatkan serangkaian latihan yang berbeda. Latihan sirkuit dipandang sebagai cara yang efektif dan efisien untuk melatih dalam waktu, jumlah, dan peralatan terbatas (Kumar, 2014:p.2). Menurut Suharjana (2013:p.49) bahwa circuit training merupakan suatu metode latihan yang terdiri dari pos-pos latihan, yaitu antara 8 sampai 16 pos latihan.

Permainan sirkuit terdiri dari beberapa pos kegiatan permainan yang dilakukan secara bertahap dan berkesinambungan. Setiap pos terdapat satu permainan yang menstimulus motorik halus anak. Setiap anak diharuskan menyelesaikan kegiatan yang ada pada setiap pos. Setiap kegiatan atau pos memunculkan kegiatan yang berisi unsur-unsur kegiatan yang disesuaikan dengan tingkat pencapaian perkembangan anak (khususnya motorik halus). Permainan sirkuit akan menjadikan perkembangan motorik anak lebih cepat terstimulus, karena kegiatan pada setiap posnya dirancang untuk demikian. Secara tidak langsung aspek perkembangan yang lainnya pun terstimulus, karena setiap aspek perkembangan saling terkait satu sama lain. Terlebih lagi melalui bentuk sirkuit ini, pola pikir anak akan terstimulus untuk lebih terpola dan terarah. Permainan sirkuit ini lebih baik dilakukan secara outdoor. Melalui permainan sirkuit ini, motorik halus anak dapat distimulasi tanpa membebani anak.

\section{METODE}

Penelitian ini merupakan jenis penelitian merupakan model Research and Development $(R \& D)$ atau penelitian dan pengembangan. Pengembangan ini mengacu pada model dari langkah-langkah Borg and Gall (1983:p.541), yaitu 1) Research And Information Collecting, 2) Planning, 3) Develop Preliminary Form Of Product, 4) Preliminary Field Testing, 5) Main Product Revision, 6) Main Field Testing, 7) Operasional Product Revision, 8) Operational field testing, 9) Final product revision, 10) Dissemination and implementation. Dari sepuluh langkah-langkah yang terdapat pada Borg and Gall, pada penelitian ini hanya menerapkan tujuh langkah penelitian saja, dan disederhanakan menjadi tiga tahap, yakni: 1) Studi Pendahuluan, 2) Pengembangan Produk, dan 3) Uji coba produk. 
Pada penelitian ini, uji coba produk digunakan untuk menguji kelayakan dan keefektivitasan pengembangan model pembelajaran berbasis permainan sirkuit pada anak. Uji kelayakan divalidasi oleh tim ahli materi, ahli media, dan praktisi. Desain dari uji efektivitas produk pada penelitian ini menggunakan metode penelitian pre-experimental design bentuk onegroup pretest-posttest design (Sugiyono, 2011:p.75).

\section{$\mathrm{O}_{1} \mathrm{X} \mathrm{O}_{2}$}

Pada penelitian ini subyek penelitian memfokuskan pada anak yang berusia 4-5 tahun. Pada ujicoba terbatas subjek ujicoba melibatkan 1 kelas anak kelompok A dari TK ABA Karangmalang sebanyak 18 anak. Sedangkan, pada ujicoba lapangan melibatkan 1 kelas dari masing-masing anak kelompok A dari TK Nasional Samirono adalah 20 anak dan TK ABA Karangmalang adalah 18 anak, sehingga jumlahnya sebanyak 38 anak. Subjek kegiatan uji efektifitas pada penelitian ini adalah Kelompok A di TK Negeri Pembina Umbulharjo sebanyak 14 anak.

Pengumpulan data digunakan sebagai alat untuk mengukur sebuah penelitian. Teknik pengumpulan data yang digunakan pada penelitian ini adalah teknik pengumpulan data dengan wawancara, angket validasi, dan observasi. Teknik analisis data dalam penelitian ini berbeda-beda sesuai dengan proses penilaian yang dijalankan dan instrumen yang digunakan. Analisis data yang digunakan pada penelitian ini adalah metode analisis deskriptif kualitatif dan analisis deskriptif kuantitatif. Pada uji efektifitas dilakukan dengan uji nonparametrik dengan uji Wilcoxon atau uji peringkat bertanda. Syarat diterimanya Ho apabila J lebih kecil atau sama dengan nilai tabel untuk N pasang (Ruseffendi, 1993:p.504).

\section{HASIL DAN PEMBAHASAN}

\section{Hasil}

Hasil penelitian merupakan hasil deskripsi data atau gambaran yang diperoleh untuk mendukung hasil penelitian. Data pada penelitian ini diperoleh melalui observasi, wawancara, dan angket validasi. Hasil dari penelitian pengembangan ini berupa langkahlangkah Model Pembelajaran berbasis Permainan Sirkuit yang dikemas atau didokumentasikan dalam bentuk $\mathrm{CD}$ dan buku panduan. Pada CD terdapat video pembelajaran yang merupakan media audio visual untuk guru dalam memahami dan melaksanakan model pembelajaran berbasis permainan sirkuit. Buku panduan pelaksanaan 
digunakan sebagai panduan guru dalam melaksanakan model pembelajaran berbasis sirkuit. Pada penelitian ini, terdapat 3 tahapan pengembangan, yakni tahap studi pendahuluan (analisis kebutuhan), tahap pengembangan (desain pengembangan produk), dan tahap ujicoba (ujicoba produk). Berikut ini, merupakan hasil dari validasi (kelayakan) dan hasil ujicoba produk.

Hasil penelitian dan pengembangan pada Kelayakan Model Pembelajaran Berbasis Permainan Sirkuit oleh validasi expert judgement.

Tabel 1. Hasil Validasi Ahli dan Praktisi pada Tahap Awal

\begin{tabular}{|c|l|c|c|c|c|}
\hline No & \multicolumn{1}{|c|}{ Nama Guru } & $\begin{array}{c}\text { Skor } \\
\mathbf{X}\end{array}$ & $\begin{array}{c}\text { Skor } \\
\text { Minimal }\end{array}$ & $\begin{array}{c}\text { Skor } \\
\text { Maksimal }\end{array}$ & Kriteria \\
\hline 1 & Dr. Rasyid Harun & 82 & 20 & 100 & Baik \\
\hline 2 & Dr. Slamet Suyanto, M.Ed & 147 & 37 & 185 & Baik \\
\hline 3 & Nur Muji Asih, S.Pd & 69 & 20 & 100 & Baik \\
\hline
\end{tabular}

Tabel 2. Hasil Validasi Praktisi pada Uji Coba Lapangan

\begin{tabular}{|c|l|c|c|c|c|}
\hline No & \multicolumn{1}{|c|}{ Nama Guru } & $\begin{array}{c}\text { Skor } \\
\mathbf{X}\end{array}$ & $\begin{array}{c}\text { Skor } \\
\text { Minimal }\end{array}$ & $\begin{array}{c}\text { Skor } \\
\text { Maksimal }\end{array}$ & Kriteria \\
\hline 1 & Nur Muji Asih, S.Pd & 84 & 20 & 100 & Sangat Baik \\
\hline 2 & Sukirni & 71 & 20 & 100 & Baik \\
\hline 3 & Tintin Wulandari, S.Pd & 79 & 20 & 100 & Baik \\
\hline
\end{tabular}

Berdasarkan hasil validasi pada tabel tersebut, dapat dilihat bahwa produk yang dikembangkan dinyatakan "baik" dan "siap" untuk diujicobakan. Hasil penelitian dan pengembangan pada Keterlaksanaan Pembelajaran pada uji coba lapangan, sebagai berikut:

Tabel 3. Hasil Observasi setiap Pos Kegiatan (Uji Coba Terbatas)

\begin{tabular}{|l|c|l|c|c|}
\hline No & Pos & \multicolumn{1}{|c|}{ Kegiatan } & $\begin{array}{c}\text { Anak yang } \\
\text { bisa }\end{array}$ & $\begin{array}{c}\text { Anak yang } \\
\text { belum bisa }\end{array}$ \\
\hline 1 & Pos 1 & $\begin{array}{l}\text { Memindahkan gambar dengan jepit } \\
\text { jemuran }\end{array}$ & $12(66,66 \%)$ & $6(33,33 \%)$ \\
\hline 2 & Pos 2 & Mengancingkan benda & $14(77,77 \%)$ & $4(22,22 \%)$ \\
\hline 3 & Pos 3 & Menggunting & $13(72,22 \%)$ & $5(27,77 \%)$ \\
\hline 4 & Pos 4 & Menggambar & $15(83,33 \%)$ & $3(16,66 \%)$ \\
\hline 5 & Pos 5 & Menuangkan air ke dalam botol & $13(72,22 \%)$ & $5(27,77 \%)$ \\
\hline \multicolumn{2}{|c|}{ Jumlah } & $\mathbf{7 4 , 4 4 \%}$ & $\mathbf{2 5 , 5 5 \%}$ \\
\hline
\end{tabular}


Tabel 4. Hasil Observasi Anak terhadap Model Pembelajaran Berbasis Permainan Sirkuit (Uji Coba Terbatas)

\begin{tabular}{|c|c|c|c|c|c|}
\hline \multirow{3}{*}{ No. } & \multirow{3}{*}{ Aspek yang diobservasi } & \multicolumn{4}{|c|}{ Anak } \\
\hline & & \multicolumn{2}{|c|}{ Ya } & \multicolumn{2}{|c|}{ Tidak } \\
\hline & & $\begin{array}{c}\text { Jumlah } \\
\text { Anak }\end{array}$ & Presentase & $\begin{array}{c}\text { Jumlah } \\
\text { Anak }\end{array}$ & Presentase \\
\hline 1 & $\begin{array}{l}\text { Kegiatan permainan sirkuit dapat } \\
\text { menarik minat anak }\end{array}$ & 14 & $77,77 \%$ & 4 & $22,23 \%$ \\
\hline 2 & $\begin{array}{l}\text { Langkah-langkah pembelajaran } \\
\text { mudah dipahami oleh anak }\end{array}$ & 16 & $88,88 \%$ & 2 & $11,12 \%$ \\
\hline 3 & $\begin{array}{l}\text { Langkah-langkah pembelajaran } \\
\text { dapat dilakukan dengan baik }\end{array}$ & 14 & $77,77 \%$ & 4 & $22,23 \%$ \\
\hline 4 & $\begin{array}{l}\text { Semua kegiatan pada masing- } \\
\text { masing pos dapat dilakukan oleh } \\
\text { anak }\end{array}$ & 15 & $83,33 \%$ & 3 & $16,67 \%$ \\
\hline & Jumlah persentase & - & $327,75 \%$ & - & $72,25 \%$ \\
\hline & Rata-rata persentase & - & $81,93 \%$ & - & $18,06 \%$ \\
\hline
\end{tabular}

Tabel 3 dan tabel 4 menggambarkan data pada setiap pos kegiatan, bahwa 74,44\% anak bisa mengerjakan setiap pos kegiatan, sehingga setiap kegiatan pada produk layak digunakan. Hasil yang didapat terhadap produk model pembelajaran berbasis permainan sirkuit secara keseluruhan memperoleh $81,93 \%$.

Tabel 5. Hasil Observasi setiap Pos Kegiatan (Uji Coba Lapangan)

\begin{tabular}{|l|c|l|c|c|}
\hline No & Pos & \multicolumn{1}{|c|}{ Kegiatan } & $\begin{array}{c}\text { Anak yang } \\
\text { bisa }\end{array}$ & $\begin{array}{c}\text { Anak yang } \\
\text { belum bisa }\end{array}$ \\
\hline 1 & Pos 1 & $\begin{array}{l}\text { Memindahkan gambar dengan jepit } \\
\text { jemuran }\end{array}$ & $33(86,84 \%)$ & $5(13,15 \%)$ \\
\hline 2 & Pos 2 & Mengancingkan benda & $35(92,10 \%)$ & $3(7,89 \%)$ \\
\hline 3 & Pos 3 & Menggunting & $32(84,21 \%)$ & $7(18,42 \%)$ \\
\hline 4 & Pos 4 & Menuangkan air ke dalam botol & $36(94,73 \%)$ & $2(5,26 \%)$ \\
\hline \multicolumn{2}{|c|}{ Jumlah } & $\mathbf{8 9 , 4 7 \%}$ & $\mathbf{1 1 , 1 8 \%}$ \\
\hline
\end{tabular}

Tabel 6. Hasil Observasi Anak terhadap Model Pembelajaran Berbasis Permainan Sirkuit (Uji Lapangan)

\begin{tabular}{|c|l|c|c|c|c|}
\hline \multirow{2}{*}{ No. } & \multirow{2}{*}{ Aspek yang diobservasi } & \multicolumn{3}{|c|}{ Observasi terhadap anak } \\
\cline { 3 - 5 } & \multicolumn{2}{|c|}{$\begin{array}{c}\text { Yumlah } \\
\text { Anak }\end{array}$} & Presentase & $\begin{array}{c}\text { Jumlah } \\
\text { Anak }\end{array}$ & Presentase \\
\cline { 3 - 6 } & $\begin{array}{l}\text { Kegiatan permainan sirkuit dapat } \\
\text { menarik minat anak }\end{array}$ & 37 & $97,36 \%$ & 1 & $2,64 \%$ \\
\hline 2 & $\begin{array}{l}\text { Langkah-langkah pembelajaran } \\
\text { mudah dipahami oleh anak }\end{array}$ & 35 & $92,10 \%$ & 3 & $7,9 \%$ \\
\hline 3 & Langkah-langkah pembelajaran & 34 & $89,47 \%$ & 4 & $10,53 \%$ \\
\hline
\end{tabular}




\begin{tabular}{|c|l|c|c|c|c|}
\hline & dapat dilakukan dengan baik & & & \\
\hline 4 & $\begin{array}{l}\text { Semua kegiatan pada masing- } \\
\text { masing pos dapat dilakukan oleh } \\
\text { anak }\end{array}$ & 38 & $100 \%$ & 0 & $0 \%$ \\
\hline$\quad$ Jumlah persentase & - & $378,93 \%$ & - & $21,07 \%$ \\
\hline & Rata-rata persentase & - & $94,73 \%$ & - & $5,26 \%$ \\
\hline
\end{tabular}

Tabel 5 dan tabel 6 menggambarkan data pada setiap pos kegiatan, terjadi peningkatan pada tahap ujicoba lapangan sebesar $15,03 \%$, yang awalnya $74,44 \%$ menjadi $89,47 \%$. Hal ini menggambarkan setiap kegiatan pada produk layak digunakan. Pada hasil yang didapat terhadap produk model pembelajaran berbasis permainan sirkuit secara keseluruhan memperoleh 94,73\%. Hal ini menandakan peningkatan dari uji coba terbatas sebesar $12,8 \%$.

Tabel 7. Deskripsi Data Hasil Penelitian

\begin{tabular}{|c|c|c|}
\hline & Pretest & Postest \\
\hline Jumlah Subjek & 14 & 14 \\
\hline Mean & 10,3 & 11,93 \\
\hline Median & 10,5 & 12 \\
\hline Modus & 11 & 12 \\
\hline Varians & 1,45 & 1,61 \\
\hline Standar Deviasi & 1,20 & 1,26 \\
\hline
\end{tabular}

Tabel 8. Hasil Uji Keefektifan dengan Uji Wilcoxon

\begin{tabular}{|l|c|c|c|c|c|c|c|c|c|c|c|c|c|c|}
\hline $\begin{array}{l}\text { Subjek } \\
\text { Penelitian }\end{array}$ & 001 & 002 & 003 & 004 & 005 & 006 & 007 & 008 & 009 & 010 & 011 & 012 & 013 & 014 \\
\hline Sebelum & 10 & 9 & 12 & 12 & 11 & 10 & 11 & 11 & 10 & 8 & 11 & 11 & 9 & 9 \\
\hline Sesudah & 12 & 11 & 14 & 12 & 10 & 11 & 13 & 14 & 12 & 10 & 12 & 13 & 12 & 11 \\
\hline Selisih & 2 & 2 & 2 & 0 & -1 & 1 & 2 & 3 & 2 & 2 & 1 & 2 & 3 & 2 \\
\hline Peringkat & 7,5 & 7,5 & 7,5 & $\mathrm{x}$ & 2 & 2 & 7,5 & 12,5 & 7,5 & 7,5 & 2 & 7,5 & 12,5 & 7,5 \\
\hline Positif & 7,5 & 7,5 & 7,5 & $\mathrm{x}$ & - & 2 & 7,5 & 12,5 & 7,5 & 7,5 & 2 & 7,5 & 12,5 & 7,5 \\
\hline J+ & 89 & & & $\mathrm{x}$ & & & & & & & & & & \\
\hline Negatif & - & - & - & $\mathrm{x}$ & 2 & - & - & - & - & - & - & - & - & - \\
\hline J- & 2 & & & $\mathrm{x}$ & & & & & & & & & & \\
\hline
\end{tabular}

Berdasarkan tabel 7 dan tabel 8 menunjukkan sehingga dapat dilihat bahwa J- lebih kecil dari J tabel, maka Ho ditolak. Dengan demikian dapat disimpulkan bahwa ada perubahan kemampuan motorik halus yang signifikan antara kemampuan anak sebelum dengan kemampuan anak sesudah perlakuan. 


\section{Pembahasan}

Motorik halus digunakan dalam kegiatan pada kehidupan sehari-hari dan pada akademik. Sejalan dengan penelitian dari Spanaki (Suryameng, 2016:p.3) menyatakan bahwa "the fine motor intervention program had a positive effect upon the graphomotor skills of kindergarten and early elementary school children". Pendapat tersebut menggambarkan jika program intervensi motorik halus memiliki dampak atau efek positif kepada keterampilan graphomotor TK dan anak SD awal. Pada usia 4-5 tahun perkembangan motorik halus anak belum seutuhnya sempurna, sehingga perlu mendapatkan stimulasi. Kegiatan diluar ruangan bisa menjadi pilihan terbaik karena dapat memberikan stimulasi perkembangan otot (baik kasar maupun halus). Peningkatan potensi psikomotorik anak akan lebih teroptimalkan jika lingkungan tumbuh kembang anak mendukung mereka untuk bergerak secara bebas (Sujarwo, 2015:p.98).

Model pembelajaran berbasis permainan sirkuit merupakan alternaif model pembelajaran yang dapat dilakukan diluar ruangan. Model pembelajaran berbasis sirkuit ini merupakan pos-pos permainan yang bertujuan untuk menstimulasi aspek perkembangan anak khususnya motorik halus. Model pembelajaran dengan permainan sirkuit menekankan tentang bagaimana pengelolaan pembelajaran yang dilakukan melalui kegiatan anak yang memiliki alur dan aturan. Model pembelajaran berbasis permainan sirkuit ini digunakan untuk menekankan tentang kegiatan pembelajaran yang bisa untuk menambah motivasi, minat, serta semangat anak dalam proses kegiatan pembelajaran. Model pembelajaran berbasis permainan sirkuit berupa langkah-langkah pembelajaran yang terdiri dari kegiatan awal, kegiatan pemanasan, kegiatan inti (permainan sirkuit), dan kegiatan akhir (pendinginan). Pada kegiatan inti, permainan sirkuit terdiri dari 4 pos kegiatan, yakni pos 1 adalah menuangkan air kedalam botol, pos 2 adalah mengancingkan benda, pos 3 adalah menjepit gambar dengan jepit jemuran, dan pos 4 adalah menggunting gambar.

Model pembelajaran berbasis permainan sirkuit yang dikembangkan layak digunakan dalam proses pembelajaran untuk meningkatkan motorik halus anak. Hal ini dibuktikan dengan hasil validasi yang dilakukan oleh ahli media, ahli materi dan praktisi telah memenuhi kriteria "baik" dan "layak" digunakan. Pada tahap uji coba produk skala terbatas dilakukan di 1 kelas dengan subjek penelitian 18 anak memperoleh 74,44\% anak mampu mengerjakan setiap pos kegiatan dan $81,93 \%$ respon positif terhadap model pembelajaran berbasis permainan sirkuit. Pada tahap uji coba produk skala lapangan melibatkan 2 kelas dan 2 sekolah dengan subjek penelitian 38 anak memperoleh memperoleh 89,47\% anak mampu 
menyelesaikan kegiatan disetiap posnya, hal ini membuktikan peningkatan $15,03 \%$ dari sebelumnya. Respon positif anak terhadap produk hasil pengembangan model pembelajaran berbasis permainan sirkuit memperoleh $94,73 \%$, hal ini menandakan peningkatan dari uji coba terbatas sebesar $12,8 \%$.

Pada tahap uji efektifitas yang dilaksanakan sebanyak 6 kali pertemuan (sudah termasuk pretest dan postest) dalam waktu satu bulan didapatkan hasil motorik halus anak meningkat. Peningkatan dilihat dari rata-rata yang meningkat sebesar 1,63 dari 10,3 menjadi 11,93. Pada penelitian ini Ho ditolak, hal ini ditunjukkan dari J- lebih kecil dari J tabel (2 lebih kecil dari 17). Dengan demikian dapat disimpulkan bahwa ada perubahan yang signifikan motorik halus antara kemampuan anak diawal dengan kemampuan anak diakhir perlakuan.

\section{SIMPULAN}

Model pembelajaran berbasis permainan sirkuit dikembangkan untuk pembelajaran motorik halus yang disesuai dengan tahap pencapaian perkembangan anak usia dini. Kegiatan-kegiatan dalam permainan sirkuit cukup mudah dilakukan dan dapat menstimulasi perkembangan motorik halus anak, seperti menuangkan air, mengancingkan benda, menjepit gambar dengan jepit jemuran, dan menggunting. Semua kegiatan mengkhusus pada melatih koordinasi gerak tangan dan mata anak, walaupun demikian secara tidak langsung juga menstimulus semua aspek perkembangan anak. Model pembelajaran berbasis permainan sirkuit ini menghasilkan video pembelajaran yang berisi langkah-langkah pembelajaran yang dikemas dalam bentuk CD dan buku panduan. Langkah-langkah pembelajaran dari model pembelajaran berbasis permainan sirkuit terdiri dari kegiatan awal, kegiatan pemanasan, kegiatan inti (permainan sirkuit), dan kegiatan akhir (pendinginan). Pertama, pada kegiatan pendahuluan guru mengkondisikan anak dengan berbaris. Anak dibimbing membentuk menjadi dua barisan dengan jumlah yang sama. Selanjutnya, anak melakukan kegiatan berdoa sesuai dengan keyakinan masing-masing. Kedua, kegiatan pemanasan dilakukan dengan cara bernyanyi dengan diiringi gerakan-gerakan ringan yang dipandu oleh guru. Tujuan dari kegiatan pemanasan ini adalah untuk mempersiapkan anak secara fisik. Berikutnya, guru memberikan arahan dan menyampaikan tujuan dan materi pembelajaran (motorik halus) serta menjelaskan aturan (sederhana) permainan yang akan dilakukan. Ketiga, kegiatan inti merupakan permainan sirkuit yang terdiri dari beberapa 4 pos kegiatan pembelajaran. Pada tahap ini, anak harus menyelesaikan kegiatan yang terdapat pada setiap pos secara urut (mulai 
dari pos satu ke pos yang lainnya). Keempat, kegiatan akhir merupakan kegiatan penutup berupa pendinginan. Pendinginan dapat dilakukan dengan gerakan ringan yang dipandu oleh guru. Hasil dari validasi yang dilakukan ahli dan juga guru didapatkan bahwa produk yang dikembangkan masuk kedalam kategori "baik".

Hasil dari pengujian pengembangan model pembelajaran berbasis permainan sirkuit dinyatakan efektif dalam meningkatkan motorik halus anak, hal ini dapat dilihat dari hasil hitung J- lebih kecil dari $\mathrm{J}$ tabel, maka Ho ditolak. Hal ini membuktikan bahwa terdapat perbedaan yang signifikan antara hasil pretest dan posttest atau adanya perbedaan antara sebelum dan sesudah perlakuan.

\section{DAFTAR PUSTAKA}

Abd, G.M. \& El M. (2016). Fine motor skill proficiency in children with and without down syndrome. Journal of Physical Therapy and Health Promotion, 4(1), 43-50.

Ali, A., Deborah P., Linda C. \& Claire M. (2017). Literature review on motor skill and physical activity in preschool children in new zealand. Advances in Physical Education, 7, 10-26.

Balasubramanian, S., \& Siddegowda. Family and child correlates of motor development of toddlers in india. International Journal Current Research and Review, January 2013, Vol 05 (02).

Bergen, D. (2009). Play as the learning medium for future scientists, mathematicians, and engineers. American Journal of Play, 4, 418-428.

Borg \& Gall. (1983). Educational Research. NewYork \& London: Longman.

Fakhruddin, A.U. (2010). Sukses menjadi guru TK-PAUD. Yogyakarta: Bening.

Hayati N., Seriati, N.N., \& Lusi, N. (2012). Kegiatan bermain berbasis art craft bagi anak usia dini untuk mempromosikan kecintaan pada lingkungan. Jurnal Kependidikan, Volume 42, Nomor 2, November 2012, Halaman 152 - 161.

Hong, J-C., Hwang, M-Y., Liu, Y-T., Lin, P-H., \& Chen, Y-L. (2016). The role of pre-game learning attitude in the prediction to competitive anxiety, perceived utility of pre-game learning of game, and gameplay interest. Interactive Learning Environments, 24(1), 239-251.

Hurlock. 1987. Perkembangan Anak Jilid 1. Jakarta: Erlangga.

Johnston, J. \& Halocha. (2010). Early childhood and primary education readings and reflections. New York: McGraw-Hill, Open University Press. 
Joyce, B.R., Marsha, W., \& Bevely, S. (1992). Models of teaching. London: Prentice-Hall International.

Kumar, M. Suresh. (2014). Influence of circuit training on selected physical fitness variables among men hockey players. International Journal of Recent Research and Applied Studies, Volume 1,Issue 7(6) December 2014.

Kurniasih, Imas. (2009). Pendidikan anak usia dini. Jakarta: Edukasia.

Madyawati, Lilis. (2016). Strategi pengembangan bahasa pada anak. Jakarta: Prenadamedia Group.

Mutiah, Diana. 2012. Psikologi bermain anak usia dini. Jakarta: Kencana Predana Media Group.

Ruseffendi. (1993). Statistik dasar untuk penelitian pendidikan. Departemen Pendidikan dan Kebudayaan Direktorat Jenderal Pendidikan Tinggi Proyek Pembinaan Tenaga Kependidikan Pendidikan Tinggi.

Rusman. (2011). Model-model pembelajaran mengembangkan profesionalisme guru. Jakarta: Rajawali Pers.

Sugiyono. (2015). Metode penelitian dan pengembangan (research and development/R\&D). Bandung: Alfabeta.

Suharjana. (2013). Kebugaran jasmani. Yogyakarta: Jogja Global Media.

Suryameng, S. (2016). Peningkatan keterampilan motorik halus kelompok A melalui bermain playdough. JPPM (Jurnal Pendidikan dan Pemberdayaan Masyarakat), 3(2), $197-$ 206. doi:http://dx.doi.org/10.21831/jppm.v3i2.10031.

Suyadi. (2010). Psikologi belajar PAUD. Yogyakarta: Pedagogia.

Whitebread, David. (2012). The importance of play. England: Toy Industries of Europe (TIE).

Winataputra, U.S. (2001). Model-model pembelajaran inovatif. Jakarta: PAU-PPAI, Universitas Terbuka.

Wastcott, Wayne. (2003). Building strength \& stamina. Human Kinetics. Massachusetts: Allyn and Bacon. Inc.

Widoyoko, Eko Putro. (2009). Evaluasi Program Pembelajaran Panduan Praktis Bagi Pendidik dan Calon Pendidik. Yogyakarta: Pustaka Belajar.

Yus, Anisa. 2011. Model pendidikan anak usia dini. Jakarta: Kencana Prenada Media Group. 